\title{
Peran Teknologi Pendidikan dalam Meningkatkan Kualitas Pendidikan di Era Disrupsi
}

\author{
Unik Hanifah Salsabila ${ }^{1}$, Munaya Ulil Ilmi ${ }^{2}$, Siti Aisyah ${ }^{3}$, Nurfadila $^{4}$, Rio Saputra ${ }^{5}$ \\ 1,2,3,4,5 Pendidikan Agama Islam , Universitas Ahmad Dahlan \\ Jalan Ring Road Selatan, Tamanan, Banguntapan, Bantul Yogyakarta 55166 \\ muilmi1403@gmail.com
}

\begin{abstract}
Along with the times, technology in its development certainly brings changes to life, especially in the world of education which will also continue to experience development. This article aims to determine the role of educational technology in improving the quality of education in this progressive era. So it is hoped that educational technologists will no longer feel doubtful and interested in adapting and being able to take advantage of technology with all its benefits in educational life. In writing this article we use a literature review method (library research), where researchers collect materials related to research from books, journals, scientific articles, literature and mass media coverage by describing and describing the data. Based on the discussion, it can be concluded that educational technology was created to solve learning problems by facilitating and providing alternatives and new innovations in the world of education. That way educational technology can make it easier to achieve educational goals.
\end{abstract}

Keywords: Technology, Education, Quality of Education

\begin{abstract}
Abstrak
Seiring dengan perkembangan zaman, teknologi dalam perkembangannya tentu membawa perubahan bagi kehidupan terutama dalam dunia pendidikan yang juga akan terus menerus mengalami perkembangan. Artikel ini bertujuan untuk mengetahui peran teknologi pendidikan dalam meningkatkan kualitas pendidikan di era yang penuh kemajuan ini. Sehingga diharapkan para teknolog pendidikan tidak lagi merasa keraguan dan tertarik untuk beradaptasi serta mampu memanfaatkan teknologi dengan segala manfaatnya dalam kehidupan pendidikan. Dalam penulisan artikel ini kami menggunakan motode tinjauan literatur (library research), dimana peneliti mengumpulkan bahan-bahan yang berkaitan dengan penelitian yang berasal dari buku, jurnal-jurnal, artikel ilmiah, literature dan pemberitaan media massa dengan cara mendeskripsikan serta menguraikan data tersebut. Berdasarkan pembahasan dapat disimpulkan bahwa teknologi pendidikan diciptakan untuk memecahkan permasalah belajar dengan cara memfasilitasi dan memberikan alternatif serta inovasi baru di dunia pendidikan. Dengan begitu teknologi pendidikan dapat mempermudah untuk mencapai tujuan pendidikan.
\end{abstract}

Kata Kunci: Teknologi, Pendidikan, Kualitas Pendidikan

Copyright (c) 2021 Unik Hanifah Salsabila, Munaya Ulil Ilmi, Siti Aisyah, Nurfadila, Rio Saputra

$\triangle$ Corresponding author: Siti Aisyah

Email Address: sitiaisyah1434@gmail.com

Received 02 Januari 2021, Accepted 06 Januari 2021, Published 06 Januari 2021

\section{PENDAHULUAN}

Pendidikan merupakan salah satu aspek penting untuk mewujudkan dan mengarahkan manusia untuk berfikir kritis dan idealis. Pendidikan bisa juga disebut mata rantai dalam kehidupan. Jika pendidikan tidak berjalan dengan semestinya, maka hal ini akan sangat berpengaruh bagi kehidupan bangsa. Maju tidaknya suatu bangsa sangat berkaitan dengan kualitas pendidikan yang dilaksanakan. Jika pendidikan yang dilaksanakan berjalan dengan baik maka bangsanya akan maju dan tentram. Generasi penerus bangsa yang sukses adalah hasil dari keberhasilan pendidikan. 
Hubungan timbal balik terjadi antara pendidikan dengan kehidupan sosial masyarakat. Oleh katena itu, pendidikan memiliki tanggungjawab besar dalam menghantarkan generasi penerus bangsa dalam menghadapi perkembangan zaman (Samsudin, 2019).

Proses perubahan tingkahlaku dan sikap seseorang dalam rangka usaha pendewasaan manusia dengan jalan pengajaran/pelatihan, proses, perbuatan mendidik adalah rangkaian aktifitas dalam pendidikan (Suryosubroto, 2002). Tak hanya itu, pendidikan juga merupakan usaha sadar dan juga terencana untuk menciptakan iklim dan proses pembelajaran agar peserta didik dapat aktif meningkatkan potensi hingga mencapai kualitas terbaik dirinya untuk masyarakat, bangsa, dan negaranya. Untuk itu perlu perlu adanya peningkatan kualitas yang dilandasi dengan iman dan takwa melalui beragam rancangan pendidikan yang dilakukan secara teratur dan terarah berkaca pada ilmu pengetahuan dan teknologi yang semakin berkembang (Tafsir, 1992).

Pendidikan berperan penting untuk mengembangkan manusia secara holistik baik dalam aspek pengetahuan, keterampilan, maupun sikap guna mempersiapkan manusia menjadi individu yang mampu memberikan manfaat dan berkontribusi secara berkelanjutan. Pendidikan sudah seharusnya dirancang agar seseorang mampun mengidentifikasi berbagai solusi atas permasalahan di masa depan. Tidak hanya sekedar untuk mempersiapkan generasi muda agar siap dan mampu bekerja saja. Akan tetapi, yang terpenting adalah pendidikan sebagai proses mempersiapkan keterampilan yang dibutuhkan guna menjadi warga yang bertanggungjawab serta terlibat langsung dalam menyelesaikan berbagai permasalahan (problem solver) di masa depan sesuai dengan perubahan dan perkembangan zaman.

Era Disrupsi, merupakan era perubahan yang mendasar dan fundamental dalam tatanan hidup manusia. Perubahan yang terjadi tidak hanya pada satu aspek kehidupan, melainkan hampir pada seluruh aspek kehidupan seperti politik, sosial, budaya, bisnis, dan pendidikan. Dalam dunia bisnis, dahulu seseorang harus membutuhkan lahan yang strategis untuk menawarkan barang daganganya. Saat ini, seseorang bisa menghasilkan puluhan juta rupiah dengan memanfaatkan gadget-nya saja. Kepala daerah yang ingin mencari masa, dahulu membutuhkan spanduk dan membutuhkan banyak biaya untuk mencetaknya. Saat ini, social media menjadi pilihan yang efektif untuk mengkampanyekan dirinya. Begitu pula dalam aspek sosial, cara interaksi antar individu bergeser dari (physical space) yang terbatas menjadi cyber space yang menghubungkan setiap individu dengan tanpa batas melalui media sosial seperti facebook, whatsapp, dan instagram.

Era disrupsi ditandai dengan adanya evolusi teknologi yang terjadi pada kehidupan manusia (Hussin, 2018). Pada era ini kita harus dapat bersikap dengan tepat. Ada dua pilihan yang dapat kita ambil, apakah kita akan menjadi disrupted (yang didisrupsi) atau menjadi disrupting (yang mendisrupsi). Untuk menjadi pribadi yang mampu mendisrupsi, kita harus mengubah mindset kita dari fixed mindset menjadi growth mindset. Mindset yang pertama cenderung tidak mau menerima perubahan sehingga menganggap bahwa perubahan dapat mengganggu kenyamanan yang telah dimiliki (gagap terhadap perubahan). Sedangkan mindset yang kedua justru mau menciptakan 
perubahan (Rosyadi \& Dkk, 2020).

Untuk dapat merubah fixed mindset menjadi growth mindset, dibutuhkan pendidikan yang layak dan berkembang sesuai dengan perkembangan zaman. Dunia pendidikan sudah seharusnya mampu membuat inovasi dan perubahan yang positif demi kemajuan pendidikan. Hal tersebut dapat tercapai apabila dalam kegiatan pendidikan dilakukan pengalihan dan pembaharuan secara global dengan memanfaatkan teknologi informasi pada aktifitas pendidikan. Pembelajaran dapat bergeser dari pembelajaran yang konvensional menjadi nonkonvensional sehingga memungkinkan siswa untuk lebih aktif dan interaktif.

Berkembangnya teknologi yang semakin canggih harus diimbangi dengan berjalannya pendidikan di sekolah. Saat ini, teknologi dengan segala kelebihnya mampu menyediakan akses informasi secara cepat dan tidak terbatas sehingga siswa dapat memperoleh materi pembelajaran dengan mudahnya. Hal ini memberikan tantangan bagi guru agar siswa tetap menjadikan guru sebagai sumber belajar yang utama bagi siswa. Guru dituntut untuk bisa beradaptasi dan menyesuaikan diri dengan segala perubahan yang ada agar mampu membimbing dan mengarahkan siswa. Guru harus mampu mengambil perananya secara tepat agar tetap menjadi pribadi yang dibutuhkan dalam membimbing, mengarahkan, memotivasi, serta mendesain pembelajaran yang berlangsung di dalam kelas.

Peningkatan kualitas, sikap positif, dan profesional dalam kegiatan belajar mengajar merupakan tujuan diterapkannya teknologi informasi dan komunikasi. Tidak hanya itu, teknologi diharapkan mempu menyelesaikan setiap permasalahan yang timbul dalam dunia pendidikan seiring dengan tantangan dan perkembangan zaman. Tidak jarang teknologi diartikan sebagai hal yang mengacu pada alat elektronik padahal hakikat teknologi memuat pengertian yang berbeda dan sangat luas yang akan dibahas lebih lanjut dalam artikel ini.

Pengertian teknologi selalu berkembang dan berubah disetiap zaman oleh masyarakat. Dahulu teknologi diartikan sebagai peralatan permesinan, radio, proyektor, hingga diartikan juga sebagai papan tulis dan buku. Saat ini teknologi seringkali diartikan sebagai alat elektronik. Namun para ahli filsafat ilmu pengetahuan beserta ilmuan mengartikan teknologi sebagai kegiatan atau pekerjaan ilmu pengetahuan yang bertujuan untuk memecahkan masalah dalam kehidupan manusia. Maka teknologi pun selalu berkaitan dengan pemasalahan karena adanya teknologi memang ditujukan untuk menyelesaikan permasalahan dan tentunya akan timbul permasalahan baru yang harus diselesaikan olehnya.

Teknologi diciptakan agar menyelesaikan permasalahan dan untuk memudahkan pekerjaan. Teknologi mempunyai peran dan kontribusi penting dalam kehidupan, tidak terkecuali bagi pendidikan yaitu untuk mengoptimalkan pembelajaran secara efektif sesuai perkembangan, kondisi, dan kebutuhan masyarakat. Peran tersebut akan dirasakan bilamana manusia dapat menerima dan beradaptasi dengan perubahan. Untuk itu, artikel ini akan mengupas mengenai peran teknologi pendidikan dalam meningkatkan kualitas pendidikan di era yang penuh kemajuan ini. Sehingga 
Peran Teknologi Pendidikan dalam Meningkatkan Kualitas Pendidikan di Era Disrupsi, Unik Hanifah Salsabila, Munaya Ulil Ilmi, Siti Aisyah, Nurfadila, Rio Saputra

diharapkan para teknolog pendidikan tidak lagi merasa keraguan dan tertarik untuk beradaptasi serta mampu memanfaatkan teknologi dengan segala manfaatnya dalam kehidupan pendidikan.

\section{METODE}

\section{Diagram Alir}

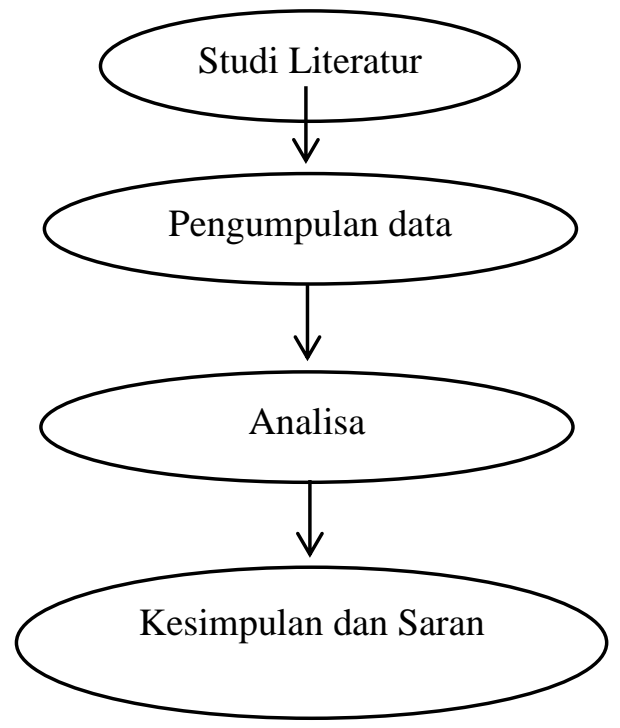

\section{Studi Literatur}

Penelitian ini menggunakan pendekatan studi pustaka atau library research. Menurut (Zed, 2004) studi pustaka adalah segala rangkaian kegiatan yang berkaitan dengan metode pengumpulan data pustaka, membaca, mencatcat serta mengolah bahan penelitian.

(Zed, 2004)Menyatakan bahwa metode studi pustaka dilakukan melalui pemanfaatan kajian lietaratur dan sumber referensi, artinya dalam melakukan penelitian kepustakaan, peneliti tidak harus turun kelapangan, cukup mencari literature dan mengolah data yang berkenaan dengan bahasan dan menyimpukannya. Dalam penelitian ini proses studi pustaka dilakukan dengan mengumpulkan data sekunder dari berbagai sumber seperti buku, jurnal, artikel ilmiah, literatur dan pemberitaan media massa online.

\section{Pengumpulan Data}

Data yang digunakan diambil dari jurnal-jurnal, buku, artikel ilmiah, literature, media online yang berkaitan dengan penelitian.

\section{HASIL DAN DISKUSI}

Teknologi pendidikan merupakan sebuah model usaha untuk merancang atau mendesain, melaksanakan serta menilai secara keseluruhan kegiatan belajar dan mengajar agar pembelajaran lebih spesifik, dengan menggunakan kombinasi sumber belajar yang praktis untuk mecapai tujuan kegiatan pembelajaran yang lebih efektif. Teknologi pendidikan dapat dimaknai sebagai suatu metode untuk 
memfasilitasi kegiatan pembelajaran dengan menggunakan atau memanfaatkan dan mengelola sumber belajar sebagai alat bantu visual dengan tepat (Januszewski, 2008). Pendapat lain menyebutkan bahwasanya teknologi pendidikan adalah proses yang menyeluruh yang di mana melibatkan manusia, metode, teori, ide, media untuk menganalisis suatu masalah, merencanakan, memilih, mengelola, serta memanfaatkan seluruh yang menyangkut dengan kegiatan pembelajaran (Munir, 2008). Dari beberapa definisi tersebut dapat diambil kesimpulan bahwa teknologi pendidikan merupakan sebuah system untuk memfasilitasi jalannya kegiatan pembelajaran baik itu perorangan maupun kelompok agar terwujudnya proses belajar dan mengajar yang efektif dan efisien, serta merupakan kegiatan pendekatan yang sistematis dan kritis dalam menyelesaikan masalah dalam pendidikan dan dapat memberikan konstribusi untuk mengembangkan potensi peserta didik.

Seiring dengan perkembangan zaman, teknologi dalam perkembangannya tentu membawa perubahan bagi kehidupan terutama dalam dunia pendidikan yang juga akan terus menerus mengalami perkembangan. Untuk itu bidang pendidikan harus selalu melakukan inovasi yang menyeluruh di karenakan bidang pendidikan memiliki peran penting dan menjadi factor yang menunjang keberhasilan system dalam proses belajar dan mengajar. Terdapat tiga prinsip yang dijadikan sebagai sumber acuan dalam mengembangkan dan memanfaatkan teknlogi pendidikan, yaitu, dengan melakukan penpengenalan system atau media yang akan digunakan, berorientasi kepada mahasiswa, dan pemanfaatakan berbagai sumber yang digunakan kegiatan pembelajaran (Sudiman et al., 2009). Pada saat ini, sering kita menjumpai proses belajar dan mengajar yang menerapkan teknologi pendidikan dengan pengkombinasian alat atau media sebagai fasilitas teknologi dalam kegiatan pembelajaran. Saat ini media pembelajaran dari produk teknologi sudah semakin berkembang dan bervariasi mulai dari yang sederhana hingga pada media pembelajaran yang canggih. Teknologi dan media pembelajaran yang digunakan harus memiliki potensi yang dapat menunjang kegiatan belajar dan mengajar serta yang paling penting adalah terjalinnya interaksi antara pendidik dan peserta didiknya. Teknologi pendidikan dapat diartikan sebagai pegangan atau pelaksanaan pendidikan secara sistematis menurut system tertentu (Nasution, 2010).

Contoh penerapan teknologi dalam bidang pendidikan seperti Zoom, Google Meet, Classroom, E-learning tersebut sudah menjadi fasilitas yang di dalam kegiatan pembelajaran dapat disampaikan melalui media elektronik seperti: audio, video, internet dan lain sebagainya sebagai instrument yang mempermudah kegiatan pembelajaran kapan pun dan di manapun. Tidak hanya itu, saat ini juga sudah banyak terdapat lembaga-lembaga kursus yang dilakukan secara online untuk membantu kagiatan pembelajaran diluar persekolahan (Jamun, 2016).

Kualitas adalah suatu indikator yang menunjukkan produk tersebut unggul dan berbobot. Dalam dunia pendidikan menurut (Depdiknas, 2001) kualitas adalah suatu tolak ukur pendidikan tersebut meningkatkan kualitas belajar yang dapat diukur secara kuantitatif, terkhusus dibidang bidang sosial. Lumrahnya kualitas dapat disimpulkan adalah suatu ciri khas tertentu yang didapat melalui proses dan revisi yang berkelanjutan. 
(Sallis Edwardis, 2006) menyatakan bahwa total quality management (TQM) sangat ideal untuk diaplikasikan dalam dunia pendidikan saat ini, dan tentunya untuk meningkatkan kualitas pendidikan saat sekarang ini yang kurang menghasilkan output yang berkualitas. Adapun teori yang berkaitan dengan kualitas pendidikan yang dapat diterapkan tersebut adalah teori total quality management (TQM), dari teori ini dijabarkan bahwasanya kualitas sekolah dapat dibagi dari 3 kepandaian, yang pertama yaitu kepandaian akademis, yang kedua kepandaian sosial dan yang ketiga adalah kepandaian moralitas. dari data tersebut kualitas sekolah dapat dijabarkan memiliki 3 variable, yakni keragaman sekolah, kegiatan proses belajar dan mengajar dan lingkungan sekolah. Keragaman sekolah adalah suatu pola prilaku yang seolah menjadi kebiasaan dilingkungan sekolah tersebut, yang dipraktekkan dari tingkat 1 ke tingkat selanjutnya yang mana nilai nilai dan kebiasaan kebiasaan tersebut yang diwariskan secara turun temurun, karena secara tidak langsung dapat membuat sebuah kebiasaan secara tidak sadar.

Adapun faktor internal sekolah adalah struktur dan kelembagaan dari sekolah tersebut. adapun yang mempengaruhinya adalah pemilihan perangkat perangkat sekolah seperti pemilihan pimpinan sekolah, guru dan sebagainya. dan faktor penting lainnya dari peningkatan kualitas pendidikan disuatu sekolah adalah bagaimana pimpinan sekolah memimpin sekolah tersebut, mulai dari kebijakan kebijakan nya dan aturan aturan yang dibuatnya akan mempengaruhi kualitas pendidikan disekolah tersebut (Zamroni, 2007).

MPMBS (Manajemen peningkatan mutu berbasis sekolah) sangat membantu sekolah untuk lancar nya program program dan untuk menyelesaikan problem problem di sekolah tersebut. dengan adanya MPMBS komponen komponen disekolah tersebut dapat berjalan sesuai porsinya masing masing dan tentunya berkaitan dengan input dan output sesuai konteksnya (Depdiknas, 2003).

Peran ialah suatu rangkaian pola pada perilaku yang diinginkan dari seseorang yang memegang posisi tertentu dalam unit social (Robbins \& Judge, 2015). Kehadiran peran dapat dimaknai sebagai penentuan suatu proses keberlangsungan. Sedangkan teknologi pendidikan tidak hanya dimaknai perangkat keras atau perangkat lunak saja, melaikan sebuah aktivitas-aktivitas yang dapat mempermudah kegiatan dalam memahami suatu dengan lebih efektif dan efesien. Tujuannya untuk memudahkan serta menekan penggunaan sumber daya, namun bisa meningkatkan hasil kerja (Darmawan, 2015). Faktor yang mempengaruhi kualitas. pendidikan di indonesia yaitu sarana dan prasarana, kualitas guru, serta kualitas peserta didik (Fajri \& Afriansyah, 2019). Dengan adanya teknologi pendidikan, telah mengubah paradigma-paradigma dalam proses pembelajaran. Yang awalnya terlihat pembelajaran dianggap kaku dan membosankan sekarang bisa fleksibel dan menyenangkan. Teknologi pendidikan akan berpusat pada perencanaan, proses perencanaan, pengembangan, pemanfaatan, pengelolaan serta mengevaluasikan sumber belajar tujuannya untuk memfasilitasi dan memudahkan dalam belajar. Mengacu pada tujuan pendidikan nasional yakni mencerdaskan kehidupan bangsa. Diharapkan bisa memberikan kesempatan bagi semua masyarakat Indonesia untuk merasakan pendidikan. 
Dalam mewujudkan kualitas pendidikan yang baik, diperlukan teknologi pendidikan untuk melahirkan SDM yang bermutu dan juga membenahi proses pendidikan dan pembelajaran yang banyak menimbulkan permasalahan belajar dimasyarakat (Achyanadia, 2016). Diperlukan pengembangkan inovasi baru pada seluruh bidang pendidikan seperti pengembangan konten dan kurikulum, penyediaan fasilitas sarana dan prasarana serta pengembangan teknologi pendidikan dalam KBM seperti pengembangan sistem maupun strategi yang lebih inovatif, yang bisa digunakan untuk semua kalangan (Mukarromah, 2017). Inovasi tidak hanya dilakukan pada tingkat pendidikan formal melaikan juga non-formal agar terwujudnya pendidikan sepanjang hayat, dimana, kapan dan oleh siapa saja tanpa batasan usia sesuai dengan konteks dan kebutuhannya (Elihami \& Saharuddin, 2018). Teknologi pendidikan memang mempunyai peran penting untuk meningkatkan kualitas dan mutu pendidikan namun juga penting untuk melaksanakan pemerataan pendidikan. Hal ini menjadi masalah didunia pendidikan jika tidak bisa ditangani, karena akan berdampak buruk bagi kehidupan masyarakat luas. Teknologi pendidikan sekiranya bisa menjadi solusi akan permasalahan yang ada, namun kembali lagi bagaimana teknologi pendidikan digunakan dengan tepat atau tidak, tergantung dengan kesiapan sember daya manusianya. Hal ini berpengaruh terhadap hasil penggunaan teknologi pendidikan. Oleh karena itu perlu pemberian pelatihan dan pengembangan bagi SDM yang bertujuan untuk membangun organisasi pendidikan yang unggul dan kompetitif.

Keberadaan teknologi pendidikan nyatanya bisa meningkatkan produktivitas pendidikan yang sekarang bisa mempercepat laju tahapan belajar, membantu pendidik memaksimalkan waktu belajar dengan baik sehingga bisa mengembangkan kegiatan belajar mengajar dengan memperluas jangkauan penyajian materi dan data lebih konkrit (Susanti, 2013). Peserta didik juga diberikan kesempatan untuk berkembang sesui dengan kemampuannya. Hal ini mengubah banyak paradigma tentang pendidik yang menjadi satu-satunya sumber belajar, sekarang banyak sekali sumber belajar yang tersedia seperti buku, jurnal, artikel, media sosial dan lainnya yang bisa digunakan sebagai sumber pelengkap. Apalagi sekarang sudah memasuki era disrupsi yang telah mengubah perilaku individu, masyarakat tanpa terkecuali dunia pendidikan. Perpindahan aktivitas yang awalnya dilakukan di dunia nyata berganti kedunia maya menandakan era ini. Tentunya didukung oleh kecanggihan teknologi yang ada. Apalagi saat ini dunia tengah dihadapkan dengan kondisi pandemi virus corona akibatnya pembelajaran dilangsungkan secara daring, mengacu pada himbauan dari Kemendikbud mengenai pengelolaan pembelajaran daring pada masa pandemi Covid-19 yang tertuang dalam SE Nomor 15 tahun 2020.

Peran Teknologi pendidikan dalam mewujudkan pendidikan yang berkualitas yaitu 1) menyediakan fasilitas belajar melalui proses perencanaan, pengembangan, pemanfaatan, pengelolaan serta mengevaluasikan sumber-sumber belajar; 2) menyelesaikan permasalahan belajar yang ada dan dikaji secara menyeluruh dengan memadukan beragam disiplin keilmuan secara terpadu; 3) memanfaatkan teknologi yang bisa membuat pekerjaan menjadi efektif dan efesien, baik itu sebagai produk maupun proses guna menyelesaikan permasalahan belajar; 4) memberikan alternatif 
penyelesain masalah kinerja organisasi pendidikan dengan terstruktur menggunakan kinerja dan desain instruksional; 5) bisa melahirkan inovasi baru dalam bidang pendidikan dan pengajaran guna memecahkan permasalahan yang ada. Peran teknologi pendidikan sangat dibutuhkan untuk meyediakan platform yang tepat untuk pembelajaran jarak jauh ini. Video conference seperti google meet dan zoom menjadi platform yang banyak digunakan diera ini pandemi ini. Diharapkan dengan ini bisa meningkatkan kapabilitas manusia dengan beragam media komunikasi dan memberikan pengalaman baru. Pendidik yang menjadi fasilitator dalam pembelajaran juga harus bisa merancang strategi pembelajaran yang dugunakan disaat era pandemi ini, agar peserta didik tidak mudah jenuh. Pembelajaran daring ini juga tidak terlepas dari permasalahan, ada positif dan negatifnya. Oleh karena itu peran teknologi pendidikan dibutuhkan agar memperkecil dampak negatif yang ditimbulkan oleh pembelajaran daring ini. Pada Hakikatnya teknologi pendidikan hadir untuk memecahkan permasalahan belajar pada manusia dimana, kapan, siapa dan dengan metode apa.

\section{KESIMPULAN}

Pendidikan berperan penting untuk mengembangkan manusia secara holistik baik dalam aspek pengetahuan, keterampilan, maupun sikap guna mempersiapkan manusia menjadi individu yang mampu memberikan manfaat dan berkontribusi secara berkelanjutan. Untuk dapat merubah fixed mindset menjadi growth mindset, dibutuhkan pendidikan yang layak dan berkembang sesuai dengan perkembangan zaman demi meningkatkan kualitas pendidikan. Saat ini, kita telah memasuki era disrupsi yang ditandai dengan kemajuan teknologi salah satunya teknologi pendidikan. Teknologi pendidikan merupakan suatu system yang digunakan untuk memfasilitasi jalannya kegiatan pembelajaran baik itu perorangan maupun kelompok organisai agar terwujudnya pembelajaran yang efektif dan efisien, serta merupakan pendekatan yang sistematis dan kritis dalam menyelesaikan masalah dalam pendidikan. Peran teknologi pendidikan dalam meningkatkan kualitas pendidikan antara lain 1) menyediakan fasilitas belajar melalui proses perencanaan, pengembangan, pemanfaatan, pengelolaan serta mengevaluasikan sumber-sumber belajar; 2) menyelesaikan permasalahan belajar yang ada dan dikaji secara menyeluruh dengan memadukan beragam disiplin keilmuan secara terpadu; 3) memanfaatkan teknologi yang bisa membuat pekerjaan menjadi efektif dan efesien, baik itu sebagai produk maupun proses guna menyelesaikan permasalahan belajar; 4) memberikan alternatif penyelesain masalah kinerja organisasi pendidikan dengan terstruktur menggunakan kinerja dan desain instruksional; 5) bisa melahirkan inovasi baru dalam bidang pendidikan dan pengajaran guna memecahkan permasalahan yang ada.

\section{REFERENSI}

Achyanadia, S. (2016). PERAN TEKNOLOGI PENDIDIKAN DALAM MENINGKATKAN KUALITAS SDM. Jurnal Teknologi Pendidikan, 5(1), 11-21.

Darmawan, D. (2015). Teknologi Pembelajara (PT. Remaja Rosdakarya (ed.)). 
Depdiknas. (2001). Manajemen Peningkatan Mutu Pendidikan Berbasis Sekolah. Depdiknas.

Depdiknas. (2003). Manajemen Peningkatan Mutu Berbasis Sekolah; Buku 1. Konsep Dasar. Depdiknas.

Elihami, E., \& Saharuddin, A. (2018). Peran Teknologi Pembelajaran Islam Dalam Organisasi Belajar. Edumaspul - Jurnal Pendidikan, 1(1), 1-8.

Fajri, I., \& Afriansyah, H. (2019). Faktor-faktor yang Mempengaruhi Rendahnya Kualitas Pendidikan di Indonesia.

Hussin, A. A. (2018). Education 4.0 Made Simple: Ideas For Teaching. International Journal of Education and Literacy Studies, 6(3), 92.

Jamun, Y. M. (2016). Desain Aplikasi Pembelajaran Peta NTT Berbasis Multimedia. Jurnal Pendidikan Dan Kebudayaan Missio, 8(1), 144-150.

Januszewski, A. (2008). Educational Technology: A Definition with Commentary. Taylor \& Francis Group.

Mukarromah, O. (2017). PERAN TEKNOLOGI PENDIDIKAN ISLAM PADA ERA GLOBAL. AnNidhom, 1(2), 91-106.

Munir. (2008). Teknologi Informasi dan Informasi (TIK). CV Alfabeta.

Nasution. (2010). Teknologi Pendidikan. PT Bumi Aksara.

Robbins, S. P., \& Judge, T. A. (2015). Perilaku Organisas (16th ed.). Salemba Empat.

Rosyadi, F. I., \& Dkk. (2020). Pola Pendidikan di Era Disrupsi. Timur Barat.

Sallis Edwardis. (2006). Total Quality Management In Education (alih bahasa Ahmad Ali Riyadi). IRCiSoD.

Samsudin, S. (2019). Peran Pendidikan Agama Islam dalam Membentuk Kepribadian di Era Disrupsi. Jurnal Pemikiran Keislaman, 30(1), 148-165.

Sudiman, A., Raharjo, R., Haryono, A., \& Harjito. (2009). Media Pendidikan: Pengertian, Pengembangan, dan Pemanfaatan. Rajagrafindo Persada.

Suryosubroto. (2002). Proses Belajar Mengajar di Sekolah. PT Rineka Cipta.

Susanti, R. (2013). Teknologi Pendidikan Dan Peranannya Dalam Transformasi Pendidikan. Jurnal Teknologi Pendidikan, 2(2), 15-23.

Tafsir, A. (1992). Ilmu Pendidikan dalam Perspektif Islam. Remaja Rosdakarya.

Zamroni. (2007). Meningkatkan Mutu Sekolah, Teori, Strategi, dan Prosedur. PSAP Muhammadiyah.

Zed, M. (2004). Metode Penelitian Kepustakaan. Yayasan Obor Indonesia. 